\section{Murderous medicine}

\author{
Nazi doctors, human experimentation, and Typhus \\ Naomi Baumslag \\ Praeger Publishers. Westport, Connecticut, USA. 2005. \\ 304 pp. \$49.95. ISBN: 0-275-98312-9 (hardcover).
}

Reviewed by Evelyne Shuster

Veterans Affairs Medical Center, Ethics and Human Rights Program, Department of Psychiatry, University of Pennsylvania,

Philadelphia, Pennsylvania, USA.

E-mail: evelyn.shuster@med.va.gov.

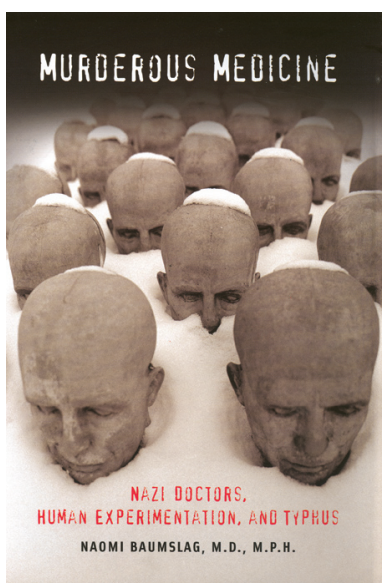

1.

n Murderous medicine Naomi Baumslag documents the complicity of Nazi doctors and pharmaceutical companies in murderous medical experiments related to epidemic typhus to further Jewish genocide. On the book's cover is a picture of the shaved heads of newly dead men, frozen in snow, with snow caps as skull caps, reminiscent of the Jewish yarmulke. Eyes and mouths are closed, forever blinded and silenced about the conditions of their deaths. Perhaps only pictures can capture the essence of Nazi medical atrocities; but pictures also limit these atrocities, which are almost too numerous to catalog.

The primary purpose of the book, subtitled Nazi doctors, buman experimentation, and Typhus, is to explain how epidemic typhus served in the extermination of Jews. It shows, for example, how Nazi officials used typhus prevention as a convenient strategy to deceive inmates into believing they were being treated when in fact they were being gassed. Jews were labeled disease carriers and a public health risk to justify the creation of ghettos. Containing typhus epidemics provided a rationale for quarantine, ghettoization, and "delousing baths" or "disinfection." Delousing baths were camouflage for gas chambers. But ghettoization, of course, fueled rather than contained the epidemic, and this, in turn, reinforced the "prevention" strategy, i.e. disinfection. German and Austrian doctors favored overcrowded and unsanitary conditions to permit the epidemic to flourish, killing as many people as possible. But why concentrate on typhus in the Jewish genocide?

Baumslag, a pediatrician at Georgetown University School of Medicine with a master of public health degree, explains that she chose to focus on typhus because the disease was rampant and the epidemic was used as a weapon of mass destruction with the "silent complicity" of the International Committee of the Red Cross (ICRC). Perhaps in an attempt to give her story more contemporary relevance, she categorizes the spread of typhus in ghettos and concentration camps as "an exemplar of biological warfare."

Baumslag argues that doctors pressured Nazi officials to proceed swiftly to quarantine and ghettoization to further the "eradication" of the disease - not typhus, but the Jews themselves. Typhus prevention rituals, including shaving and gassing, were used under the subterfuge of providing health care. Several million Jews were murdered as a direct consequence. Underlining the point that the goal was to kill Jews, she notes, "with all their barbaric and unethical experiments the German researchers were unable to control typhus and get rid of lice." Jews were left in a diseased environment and doomed to die.

It is an important story, and one well worth documenting. It is not, however, an example of "biological warfare," which requires one or more countries fighting to subjugate another country. Jews did not have their own country, nor did other groups Germans despised and killed, such as homosexuals and Romanys. This is about using medicine and public health for killing. As Robert Proctor perceptively notes, "Germany had two systems of occupational health and safety: one for the racially desirable and one for the racially inferior. Most of the ordinances protecting 'decent healthy Germans' were formalized by law; many of the abuses suffered by 'racial inferiors' were perpetrated in a legal gray area confused by the exigencies of war and the disregard for international human rights" (1). Baumslag also misses the point when she claims that German doctors were not acting as physicians when they quarantined Jews and others because "it makes no sense to create and promote conditions that are adverse to public health.” But these German physicians did not abide by medical and public health ethics. To fight the epidemics with hygiene and proven preventive measures was not an option where Jews were concerned. From the perspective of Nazi racial hygiene, Jews were the disease on the German body politic.

Baumslag concludes that we still face the challenge of educating doctors, health care workers, and researchers "to have a conscience and a love for humankind." Ultimately, "there is no medical science without a moral basis." Baumslag is, of course, correct, as were the American judges at Nuremberg who sat in judgment of the Nazi doctors at the Doctors' Trial (2). A similar point could also be made about humanitarian organizations such as the ICRC, which, tragically, failed to report on and expose the true conditions of concentration camps such as Theresienstadt and Auschwitz.

Typhus prevention was one of the many pretenses used by Nazis to achieve "racial purity." But the Jewish genocide cannot be adequately explained or understood from the perspective of a single disease, even one as devastating as typhus. Nonetheless, those who continue to ponder Nazi medical atrocities and want to reflect on the moral failures of Nazi doctors, pharmaceutical companies, and humanitarian organizations will find this book useful. Those interested in contemporary challenges of bioterrorism and biowarfare, however, will find books such as Madeline Drexler's Secret agents: the menace of emerging infections and Jonathan Tucker's Scourge: the once and future threat of smallpox more relevant.

1. Proctor, R.N. 1999. The Nazi war on cancer. Princeton University Press. Princeton, New Jersey, USA. 364 pp.

2. Shuster, E. 1997. Fifty years later: the significance of the Nuremberg Code. N. Engl. J. Med. 337:1436-1440. 